\title{
Optimizing Multi-Response Parameters in Turning of AISI1040 Steel Using Desirability Approach
}

\author{
Srinu Gugulothu*, Vamsi Krishna Pasam \\ Department of Mechanical Engineering \\ National Institute of Technology Warangal, Telangana, India \\ ${ }^{*}$ Corresponding author: srinu72210@ gmail.com
}

(Received March 5, 2019; Accepted May 20, 2019)

\begin{abstract}
In this study, an attempt is made to examine the machining response parameters in turning of AISI 1040 steel under different lubrication environment. Subsequently, design of experiment technique Response surface methodology (RSM) is used for analyzing machining performance by varying cutting conditions with the use of $2 \mathrm{wt} \%$ of $\mathrm{CNT} / \mathrm{MoS}_{2}(1: 2) \mathrm{HNCF}$. Regression models are developed for multiple machining responses. Optimization is performed for these models by using desirability function, which converts multi-objective into single objective. Then the optimal setting parameters for single objective is found. Significant reduction in main cutting force $\left(\mathrm{F}_{z}\right)$, cutting temperature $(T)$, surface roughness $\left(\mathrm{R}_{\mathrm{a}}\right)$ and tool flank wear $\left(\mathrm{V}_{\mathrm{b}}\right)$ are found with the use of $2 \mathrm{wt} \%$ of $\mathrm{CNT} / \mathrm{MoS}_{2}(1: 2)$ HNCF compared to other lubrication environment. Significant factors that affect the main cutting force (Fz), the temperature in the cutting zone are cutting speed, feed rate and depth of cut. Parameter depth of cut has an insignificant effect on tool flank wear and surface roughness $\left(R_{a}\right)$. The optimal cutting conditions for four multi-objective optimization of main cutting force $\left(\mathrm{F}_{\mathrm{z}}\right)$, cutting temperature, surface roughness $\left(\mathrm{R}_{\mathrm{a}}\right)$ and tool flank wear are found to be cutting speed $70.25 \mathrm{~m} / \mathrm{min}$, feed $0.13 \mathrm{~mm} / \mathrm{rev}$ and doc $0.5 \mathrm{~mm}$ at desirability value of 0.907 .
\end{abstract}

Keywords- Machining, Response surface methodology, Hybrid nano cutting fluid, CNT, MoS2, Optimization.

\author{
Abbreviations \\ RSM- Response Surface Methodology \\ HNCF- Hybrid Nano Cutting Fluid \\ CCF- Conventional Cutting Fluid \\ CS- Cutting Speed \\ FR- Feed Rate \\ DOC- Depth of Cut \\ MQL- Minimum Quantity Lubrication
}

\section{Introduction}

Turning is one of the widely used machining operations in production industries. Cutting conditions, which include cutting speed (CS), feed rate (FR), and depth of cut (DOC) play a key role for improving productivity. The CS is the more eminent factor among the other parameters during dry cutting, which effects generating heat in the deformation zone. Generated heat in the machining zone affects the sharpness of tool and reduces the tool life, which gives a poor surface finish. Therefore, usage of the cutting fluid is necessary for removing heat in the cutting zone. Besides cooling and lubrication, cutting fluids performs other functions such as flushing the chips away from cutting area, protects the part against oxidation, provides longer life of the tool and improves the surface quality of the machined part (Amrita et al., 2014). To some extent this may serve the purpose but it leads to drastic situations like difficulty in the disposal of cutting fluid 
International Journal of Mathematical, Engineering and Management Sciences

Vol. 4, No. 4, 905-921, 2019

https://dx.doi.org/10.33889/IJMEMS.2019.4.4-072

that causes environmental pollution such as water, air and soil contamination, skin and health issues of the operator. Therefore, to minimize the bulk usage of cutting fluids researchers focused their research on various alternatives. Some of them were dry machining, Minimal Quantity Lubrication (MQL), solid lubricants, vegetable oil and nanofluids.

To minimize the excessive coolant, MQL is the most eminent technique for supplying minimum quantity of coolant to exact cutting area at high pressure with certain flow rate $(5-10 \mathrm{~mL} / \mathrm{min})$ in the form of mist generation (Krishna and Rao, 2008). Marques et al., (2016) reported the enhancement in surface integrity of workpiece and life of cutting tool with the inclusion of graphite nanoparticle in neat oil compared to $\mathrm{MoS}_{2}$ (Molybdenum di sulfide) in turning of Inconel 718 using MQL mode. Apart from the MQL, solid lubricants also play a vital role for effective machining by enhancing the surface integrity and tool life due to their structure, eco and environmental friendly characteristics. Some of them are boric acid, $\mathrm{WS}_{2}$ (Tungsten di sulfide), $\mathrm{MoS}_{2}$, graphite etc. $\mathrm{MoS}_{2}$ is widely used solid lubricant among the others due to low friction properties. Friction reduction property is achieved due to paralleled lamellar structure of $\mathrm{MoS}_{2}$ solid lubricant with strong covalent bond within layer and the weaker bond between the layers to layer. Such layers of $\mathrm{MoS}_{2}$ solid lubricant made it to achieve low friction properties when sliding against each other with a minimum load. Rahmati et al. (2014) studied the performance of nano $\mathrm{MoS}_{2}(20-60 \mathrm{~nm})$ enriched with oil in various concentrations $(0,0.2,0.5$ and $1 \mathrm{wt} \%)$ in milling under MQL condition. They inferred that the surface roughness was reduced with the particle concentration of $0.5 \mathrm{wt} \%$. Paturi et al. (2016) reported the reduction in $\mathrm{R}_{\mathrm{a}}$ value about $35 \%$ than pure MQL by adding the $\mathrm{ws}_{2} 0.5 \mathrm{wt} \%$ solid lubricant in emulsifier oil in turning of Inconel 718.

Besides solid lubricants in machining, vegetable oil is also one of the major alternatives for minimizing the cost of fluid disposal and environmental issues with conventional cutting fluid. Vegetable oil posses the properties of high biodegradability, high viscosity index, and low production cost (Lawal et al., 2014). Vegetable oils consist of triglycerides, means three longchain fatty acids of glycerol's are attached to hydroxyl group. The triglyceride structure of vegetable oil is providing high quality desirable characteristics of boundary lubrication. The structure of long chain polar fatty acids in vegetable oil enhance the strength of durable layer of lubricant film that can interact with workpiece surface and reduce both wear and friction coefficient when the surfaces were in contact (Lawal, 2013). Suspensions of millimeter or micron size of solid particles settled quickly in fluids can cause a problem like abrasion or blocking of the supply channels. To restrict these challenges nano sized particles are put back the micron particles. Nanoparticles are stably suspended in base fluids for longer duration. Nano fluids are the fluids obtained by suspending the nano particle with an average size less than $100 \mathrm{~nm}$ in liquids. Generally solid have the high heat carrying capacity than liquids. Though nanoparticles dispersing into the base fluid, less percentage by weight can improve the basic properties like thermal conductivity, kinematic viscosity, convective heat transfer coefficient etc, due to shape, size and large surface to volume ratio of the nanoparticle. Soybean oil with the inclusion of $\mathrm{MoS}_{2}$ $(3-5 \mu \mathrm{m})$ solid particles with MQL mode was performed better than paraffin oil based nanofluid in grinding in terms of reduction in specific grinding energy, coefficient of friction and grinding ratio (Kalitha et al., 2012).In addition to mono type cutting fluids, the combination of different nano sized material or solid particles in base fluid (it is termed as hybrid type nano fluids) performing better in machining. Very few investigations were in process on hybrid nanofluids in machining (Mechiri et al., 2015; Zareie and Akbari, 2017; Singh et al., 2017). 
International Journal of Mathematical, Engineering and Management Sciences

Vol. 4, No. 4, 905-921, 2019

https://dx.doi.org/10.33889/IJMEMS.2019.4.4-072

Optimization is a process for finding the best solution when more number of feasible solutions is available. Few investigations were also in processes for finding the optimal solution in the combination of different cutting parameters for the machining response variable.

It is observed from the literature that the machining performance was improved by using the MQL technique. It was also reported that MQL, solid lubricants and vegetable oil based nanofluid has improved the surface finish of the machined component. The current study is motivated by the improved thermophysical properties of HNCF and an attempt is made to evaluate the machining performance in turning of AISI1040 steel under different lubrication environments and comparative assessment is made. Subsequently, machining experiments are designed by varying cutting conditions using RSM technique. Optimization is performed for multiple responses by using desirability function which converts multi-objective into single objective and optimal setting parameters for single objective is found.

\section{Experimentation}

Turning experiments were performed at constant cutting conditions under different lubrication environment and varying cutting conditions under MQL technique with the aid of $2 \mathrm{wt} \%$ of $\mathrm{CNT} / \mathrm{MoS}_{2}(1: 2) \mathrm{HNCF}$. Workpiece material used for machining in the current study is chosen from the literature (Krishna and Rao, 2008).

\subsection{Formulation of Hybrid Nano Cutting Fluid (HNCF)}

The nano particles CNT (100nm outer diameter, 30nm inner diameter and 1micron length) and $\mathrm{MoS}_{2}(30 \mathrm{~nm})$ are procured from Ishu international, New Delhi. Sesame oil and sodium dodecyl sulfate surfactant were procured from the local market. Pure CNT, pure $\mathrm{MoS}_{2}$ and CNT/MoS $(1: 2)$ nano additives were used in sesame oil at concentration of $2 \mathrm{wt} \%$ to obtain nanofluids using two-step method (Padmini et al., 2015). Sodium dodecyl sulfate (SDS) was chosen as surfactant and added in net quantity of fluid (i.e. $15 \%$ by weight of included nanoparticle) for improving stability of pure and hybrid nano fluids (Pasam and Gugulothu, 2018). Thus prepared nanofluids were performed manual mixing followed by ultra sonication for 3hours by using (Piezo-U-sonic, $100 \mathrm{~W}$, ultrasonic processor at $22.54 \mathrm{KHz}$ ) to get stable suspensions and used in machining.

\subsection{Experimental Conditions}

Machining of AISI1040 steel was performed on the lathe (Magnum make, 10hp power capacity) with carbide insert (CNMG120408TTS; widia make) under different lubrication environment at constant and varying cutting conditions. The carbide insert was clamped with screw on (PCLNR2525M120; widia make) tool holder during machining. Cutting conditions and lubrication environment during turning experiments were depicted in Table 1 . The $2 \mathrm{wt} \%$ of $\mathrm{CNT} / \mathrm{MoS}_{2}$ (1:2) HNCF was supplied to an exact cutting area through MQL mode during machining with variable cutting conditions (Pasam and Gugulothu, 2018). Compressed air pressure was always maintained minimum at 4 bar for delivering cutting fluid with $10 \mathrm{~mL} / \mathrm{min}$ flow rate on the cutting tool. Main cutting force $\left(\mathrm{F}_{\mathrm{z}}\right)$ was recorded online with six components dynamometer (make: Kistler; model: 9257B). In the analysis, the mean value of the main cutting force $\left(\mathrm{F}_{\mathrm{z}}\right)$ force was considered over the regular time. $\mathrm{K}$ type embedded thermo couple was used to measure the cutting temperature by fixing at the bottom position of the tool inserts in the tool holder. Image of the cutting tool and thermocouple provision for temperature measurement in turning operation is shown in Figure 1. Surface roughness $\left(\mathrm{R}_{\mathrm{a}}\right)$ and tool flank wear were measured offline after each turning operation by using the Taylor Hobson surface roughness tester (model: Surtronic- S128) and tool makers microscope (Make: Mitutoyo). For all the 
International Journal of Mathematical, Engineering and Management Sciences

Vol. 4, No. 4, 905-921, 2019

https://dx.doi.org/10.33889/IJMEMS.2019.4.4-072

machining responses, the average value of three experimental runs was considered in the analysis. The experimental setup for turning under MQL is shown in Figure 2.

Table 1. Cutting conditions for turning of AISI 1040 steel

\begin{tabular}{|l|l|}
\hline Lubrication environment & Dry, CCF, nanofluid, HNCF \\
\hline Constant cutting conditions & CS: $80 \mathrm{~m} / \mathrm{min}$, FR: $0.161 \mathrm{~mm} / \mathrm{rev}$ and DOC: $0.5 \mathrm{~mm}$ \\
\hline
\end{tabular}

\subsection{Design of Experiments}

Response surface methodology is a technique that involves various complex calculations for optimization. This approach builds up experimental design that integrates all the independent variables and uses the experimental data to develop the set of equations for each output parameter. The outputs are attained from the well-designed regression analysis that is based on independently controllable input factors. Subsequently, response variables are predicted using new values of input variables. This approach has two important functions in statistics, one being the establishment of correlation between several independent input factors and one or more response variable, second is to evaluate the response variable by changing the different input factors. Each and every response $(y)$ is influenced by different input factors $\left(x_{i}, x_{j}\right.$,). The established correlation between independent input factors and the response variable is represented by the following polynomial equation (1).

$y=f\left(x_{1}, x_{2}, x_{3} \ldots \ldots x_{k}\right)$

The first order model is not used for optimization due to lack of fit. Second order model improves optimization for the response variable due to more interaction effects of the several independent input factors. A general form of the second order model is represented as

$\mathrm{y}=a_{0}+\sum_{i=1}^{n} a_{i} x_{i}+\sum_{i=1}^{n} a_{i i} x_{i}^{2}+\sum_{i=1}^{n} \sum_{j=1}^{n} a_{i j} x_{i} x_{j}: i<j$

where $a_{0}$ constant

$a_{i}, a_{i i}, a_{i j}$ are the coefficients for the quadratic model

$x_{i}, x_{j}$ are the input factors.

Cutting parameters were optimized with Box-Behnken design in RSM tool to get the desired response value. Levels chosen in Box-Behnken design are low, medium and high which coded as $-1,0$ and 1 . Total 15 experimental runs were considered in this design with three centre points. The independent input factors with their values and levels are chosen in the present work were presented in Table 2 and response variables noted during machining are presented in Table 3. For experimental design and building of the model design expert software was used. The regression analysis of experimental data was also carried out by using the same. The quality of the fit for second order model is checked with the value of $\mathrm{R}^{2}$ and $\mathrm{R}^{2}$ adjusted. The point optimization was used for multiple response parameters and values of optimal setting parameters were found. 
International Journal of Mathematical, Engineering and Management Sciences

Vol. 4, No. 4, 905-921, 2019

https://dx.doi.org/10.33889/IJMEMS.2019.4.4-072

Table 2. Chosen varying cutting conditions and levels

\begin{tabular}{|c|c|c|c|c|}
\hline Factors & Units & \multicolumn{3}{|c|}{ Levels } \\
\hline & & -1 & 0 & +1 \\
\hline CS & $(\mathrm{m} / \mathrm{min})$ & 60 & 80 & 100 \\
\hline FR & $(\mathrm{mm} / \mathrm{rev})$ & 0.131 & 0.161 & 0.191 \\
\hline DOC & $(\mathrm{mm})$ & 0.5 & 0.75 & 1 \\
\hline
\end{tabular}

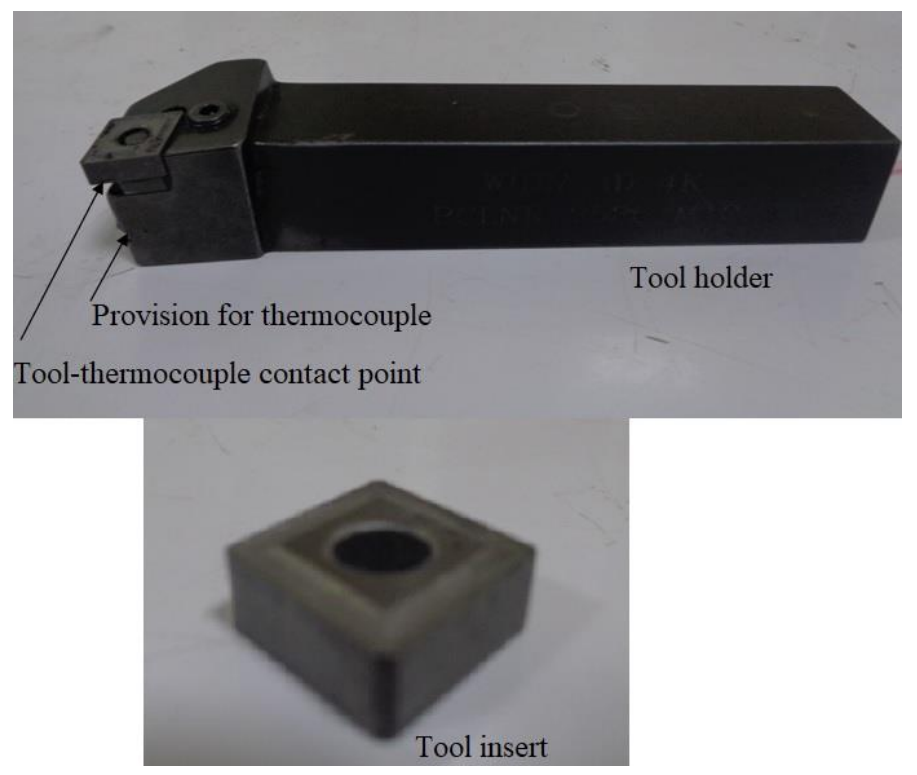

Figure 1. Cutting tool and tool holder

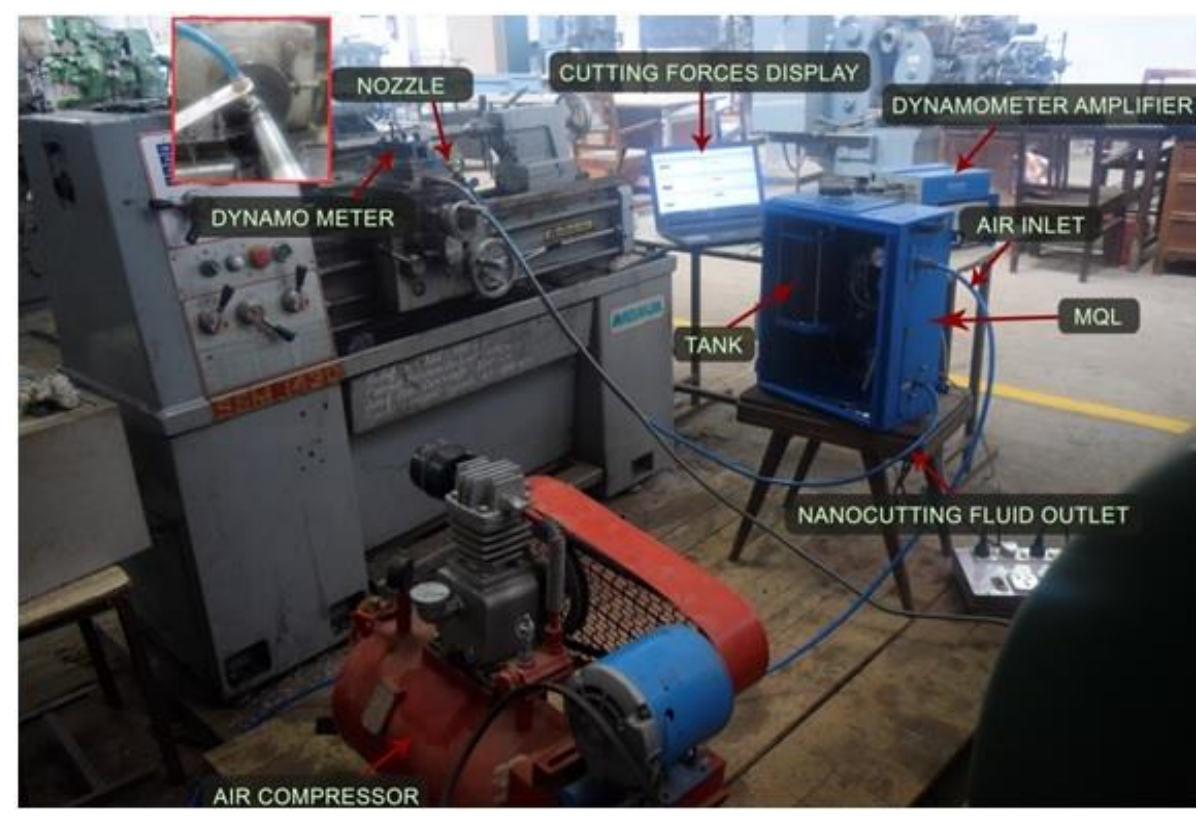

Figure 2. Machining experimental setup for turning under minimal quantity lubrication 
International Journal of Mathematical, Engineering and Management Sciences

Vol. 4, No. 4, 905-921, 2019

https://dx.doi.org/10.33889/IJMEMS.2019.4.4-072

\subsection{Desirability}

Selecting the optimal combination of process parameter for desired response parameters is a challenging task in machining because of a large number of input parameters. Derringer and Suich illustrate a method for optimization of multiple responses is called desirability (El-Taweel and Gouda, 2011). This method is widely used in industry for optimization of multiple responses to get optimal process parameters for the improved response variable. The objective function of this method is called the desirability function denoted by $\mathrm{D}(\mathrm{X})$. The objective form of the desirability function is the geometric mean of all the responses. A range of the desirability is (0 to 1) the value near to 1 is the most desirable and ideal case and the value 0 indicate that responses are outside the limits. The optimal combination for multiple responses is selected based on combined desirability, which considered to be maximum. The geometric mean of individual desirability gives the overall desirability (D).

$D=\left(d_{1} y_{1} \cdot d_{2} y_{2} \ldots . d_{k} y_{k}\right)^{1 / k}$

where $\mathrm{K}$ is the number of response parameters, $\mathrm{y}$ is the response value.

\subsection{Machining Performance at Constant Cutting Conditions}

Main cutting force $\left(\mathrm{F}_{\mathrm{z}}\right)$ during turning of AISI1040 steel with different lubrication environment is presented in Figure 3. It is observed that the main cutting force is less in case of $2 \mathrm{wt} \%$ of $\mathrm{CNT} / \mathrm{MoS}_{2}(1: 2) \mathrm{HNCF}$ compared to other lubrication environment. This improvement is due to enhanced physical and thermal properties of HNCF compared to single nanoparticle enriched cutting fluids. Both CNT and $\mathrm{MoS}_{2}$ nanoparticles have different structure, shape and lubrication effect. $\mathrm{MoS}_{2}$ is a lamellar structure that can easily adsorb on the metal surface and create an adhesive film on contact surfaces to reduce the friction and thus decrease the value of main cutting force $\left(\mathrm{F}_{\mathrm{z}}\right)$ (Padmini et al., 2016). CNT nanoparticle is like a tube structure with high strength due to high carbon content and high aspect ratio. Hence, CNT could act as similar to bearings but agglomerates easily and gives poor lubrication effect. The high strength of CNT nanoparticle would prevent in the failure of lubrication effect. Mixing of CNT with $\mathrm{MoS}_{2}$ at 1:2 proportions in base oil improve the lubricity effect by preventing the agglomeration of CNT. From the experimental findings, main cutting force $\left(\mathrm{F}_{\mathrm{z}}\right)$ is found to lower with HNCF compared to pure CNT and pure $\mathrm{MoS}_{2}$ nanofluids at same mass concentration due to the synergistic effect of CNT and $\mathrm{MoS}_{2}$ (Zhang et al.,2015; Zhang et al., 2016). All the above discussed affirmative factors help in reducing main cutting force.

Cutting temperature $\left(\mathrm{T}^{\circ} \mathrm{C}\right)$ observed during machining with different lubrication environment is presented in Figure 4. Cutting temperature $\left(230^{\circ} \mathrm{C}\right)$ is found in dry, CCF $\left(180^{\circ} \mathrm{C}\right)$, pure $\mathrm{CNT}$ nanofluid $\left(152^{\circ} \mathrm{C}\right)$, pure $\mathrm{MoS}_{2}$ nanofluid $\left(160^{\circ} \mathrm{C}\right)$ and $\mathrm{HNCF}\left(140^{\circ} \mathrm{C}\right)$ conditions respectively. The temperature in cutting zone is found to reduce by $43.4 \%, 28 \%, 8 \%$ and $12.5 \%$ with $2 \mathrm{wt} \%$ of $\mathrm{CNT} / \mathrm{MoS}_{2}$ (1:2) HNCF compared to dry, CCF, $2 \mathrm{wt} \%$ of pure CNT and pure $\mathrm{MoS}_{2}$-nanofluids respectively. Application of low friction coefficient of nano $\mathrm{MoS}_{2}$ solid lubricant during sliding surfaces reduces the friction by maintaining consistent film with sesame oil and result in lower heat generation thus leads to lower cutting temperature. High thermal conductivity of CNT improves heat transfer rate and enhances the heat dissipation during machining and control the temperature in cutting zone. Combination of the both CNT and $\mathrm{MoS}_{2}$ nanoparticles at (1:2) proportion in base oil enhances lubrication and cooling performance of CNT/MoS 2 HNCF due to good synergistic effect and ball bearing effect and results in lower cutting temperature (Sharma et al., 2015). 
International Journal of Mathematical, Engineering and Management Sciences

Vol. 4, No. 4, 905-921, 2019

https://dx.doi.org/10.33889/IJMEMS.2019.4.4-072

Figure 5 presents surface roughness $\left(\mathrm{R}_{\mathrm{a}}\right)$ results in different lubrication environment. Surface roughness $\left(\mathrm{R}_{\mathrm{a}}\right)$ is found to be least with $\mathrm{HNCF}(2 \mu \mathrm{m})$ among the other mode of lubrication. Surface roughness $\left(\mathrm{R}_{\mathrm{a}}\right)$ value is found to reduce by $28.5 \%, 18.3 \%, 13 \%$ and $9 \%$ with the use of $2 \mathrm{wt} \%$ of CNT/MoS 2 (1:2) HNCF compared to dry condition, CCF, pure CNT and pure $\mathrm{MoS}_{2}$ nanofluids. This may be due to dissimilar nanoparticle combination in base oil, which tends to form proper film when the surfaces were in contact, which reduces the coefficient of friction thereby reducing the cutting force (Rapeti et al., 2018). The decrease in cutting force and temperature in machining zone imparts better surface finish.

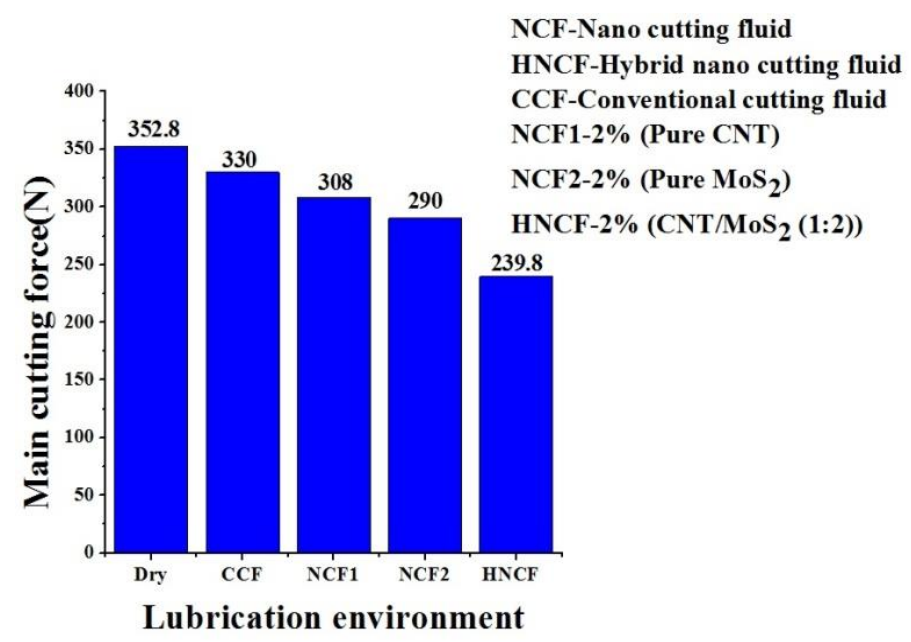

Figure 3. Variation of main cutting force with different lubrication environment $(\mathrm{CS}=80 \mathrm{~m} / \mathrm{min}$, $\mathrm{FR}=0.161 \mathrm{~mm} / \mathrm{rev}$ and $\mathrm{DOC}=0.5 \mathrm{~mm}$ )

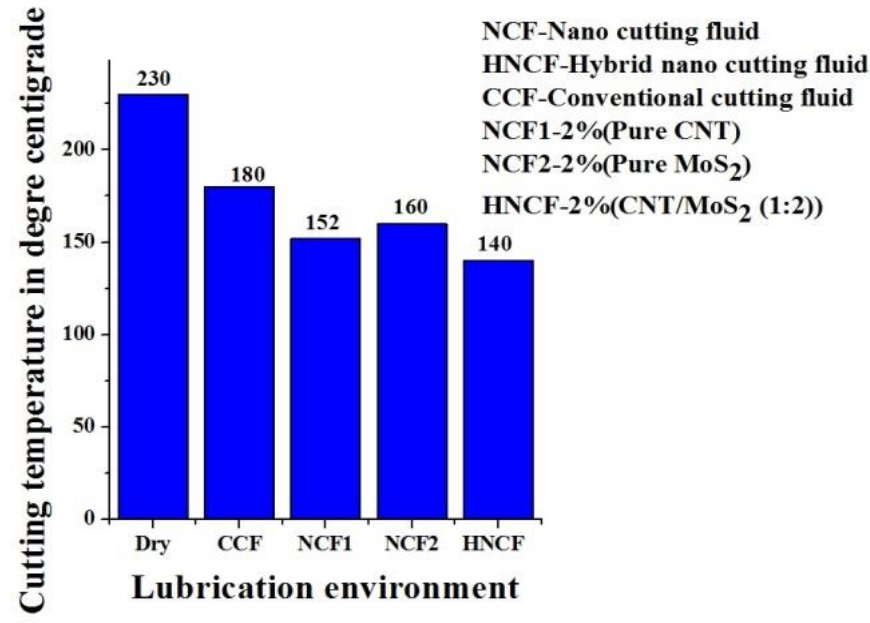

Figure 4. Variation of cutting temperature with different lubrication environment $(C S=80 \mathrm{~m} / \mathrm{min}, \mathrm{FR}=0.161$ $\mathrm{mm} / \mathrm{rev}$ and $\mathrm{DOC}=0.5 \mathrm{~mm})$ 
International Journal of Mathematical, Engineering and Management Sciences

Vol. 4, No. 4, 905-921, 2019

https://dx.doi.org/10.33889/IJMEMS.2019.4.4-072

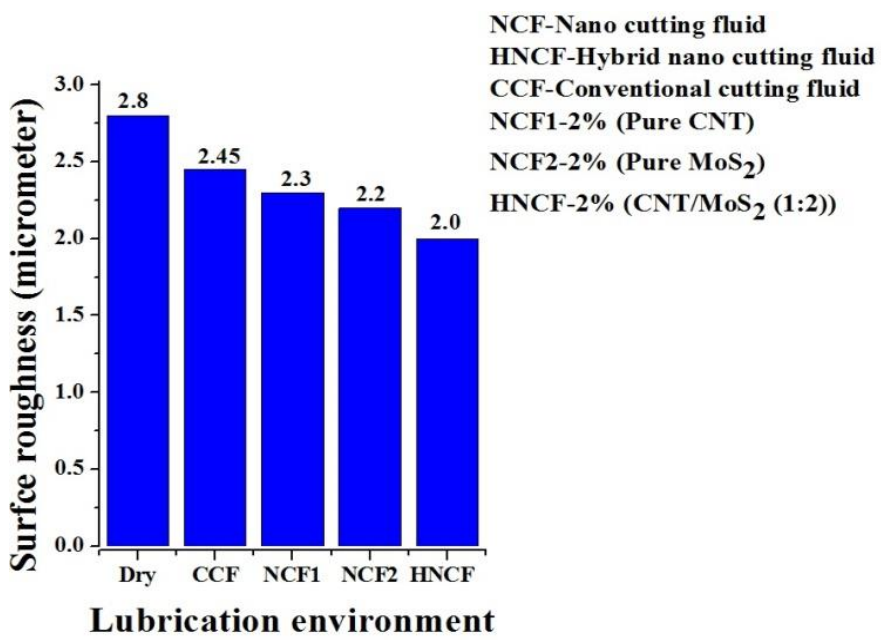

Figure 5. Variation of surface roughness $\left(R_{a}\right)$ with different lubrication environment $(C S=80 \mathrm{~m} / \mathrm{min}, F R=$ $0.161 \mathrm{~mm} / \mathrm{rev}$ and $\mathrm{DOC}=0.5 \mathrm{~mm}$ )

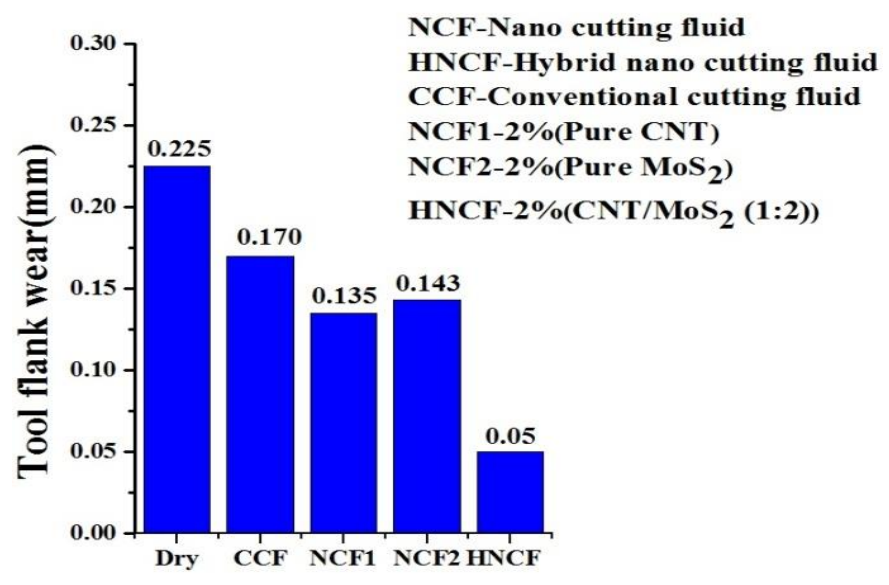

Lubrication environment

Figure 6. Variation of tool flank wear with different lubrication environment $(\mathrm{CS}=80 \mathrm{~m} / \mathrm{min}, \mathrm{FR}=0.161$ $\mathrm{mm} / \mathrm{rev}$ and $\mathrm{DOC}=0.5 \mathrm{~mm}$ )

Tool flank wear during machining with different lubrication environment is presented in Figure 6. It is noticed that maximum tool flank wear is found with dry machining $(0.225 \mathrm{~mm})$ and least with $2 \mathrm{wt} \%$ of $\mathrm{CNT} / \mathrm{MoS}_{2}(1: 2) \mathrm{HNCF}(0.05 \mathrm{~mm})$. The tool flank wear is found to reduce by $77.8 \%$, $70.5 \%, 63 \%$ and $65 \%$ with $2 \mathrm{wt} \%$ of $\mathrm{CNT} / \mathrm{MoS}_{2}(1: 2) \mathrm{HNCF}$ compared to dry condition, CCF, $2 \mathrm{wt} \%$ of pure CNT and pure $\mathrm{MoS}_{2}$ nanofluids respectively. The weak structure of $\mathrm{MoS}_{2}$ easily forms slicing layers because of the shearing action of chip on the cutting tool. This provides better film formation on sliding surfaces thus reduce the plastic contacts and the resulting reduction in tool flank wear. The synergistic effect of CNT and $\mathrm{MoS}_{2}$ nanoparticles at 1:2 proportions in sesame oil and ball bearing effect of nano $\mathrm{MoS}_{2}$ could reduce the tool flank wear (Zhang et al., 2016). 
International Journal of Mathematical, Engineering and Management Sciences

Vol. 4, No. 4, 905-921, 2019

https://dx.doi.org/10.33889/IJMEMS.2019.4.4-072

\subsection{Machining Performance by Varying Cutting Parameters}

Turning experiments also conducted on lathe by varying cutting parameters in the machining of AISI 1040 steel as per experimental design (Table 3) and responses are noted. The variance of responses during machining are analyzed with an objective of influence of cutting conditions on responses.

It is noticed from Figure 7 (a-c) that the augment in the main cutting force $\left(\mathrm{F}_{\mathrm{z}}\right)$ is found with an increase in CS up to $80 \mathrm{~m} / \mathrm{min}$ and then slightly diminishes for further increment. Continuous increase in trend is found with an increase in FR and DOC. This is due to the higher area of chip tool interface during machining processes. The least main cutting force $\left(\mathrm{F}_{\mathrm{z}}\right)$ is recorded at lower levels of CS $(60 \mathrm{~m} / \mathrm{min})$ and $\mathrm{FR}(0.131 \mathrm{~mm} / \mathrm{rev})$ at the middle level of DOC $(75 \mathrm{~mm})$. ANOVA is performed at $95 \%$ (5\% significance) level for the main cutting force $\left(\mathrm{F}_{\mathrm{z}}\right)$, which is summarized in Table 4. The developed quadratic model for main cutting force $\left(\mathrm{F}_{\mathrm{z}}\right)$ is found to be significant and lack of fit is found to be non significant. From the ANOVA results, the P value of the model is 0.0001. Hence, the model and its terms CS, FR and DOC are statistically significant on the main cutting force (Gopalakannan and Senthilvelan, 2014). The regression model values of $\mathrm{R}^{2}$ and $\mathrm{R}^{2}$ adjusted for the main cutting force are equal to 0.9997 and 0.9993 . The values of $\mathrm{R}^{2}$ predicted and adequate precision is equal to 0.9962 and 137.218. From the adequate precision value, it is understood that the model is better fitted.

The regression model for the main cutting force $\left(\mathrm{F}_{\mathrm{z}}\right)$ is as follows.

Main cutting force $\left(\mathrm{F}_{\mathrm{z}}\right)=-10440.01042+98.66083 \times \mathrm{CS}+65025.000 \times \mathrm{FR}+$ $3178.5334 \times \mathrm{DOC}+50.4167 \times \mathrm{CS} \times \mathrm{FR}+4.300 \times \mathrm{CS} \times \mathrm{DOC}-13866.66667 \times \mathrm{FR} \times \mathrm{DOC}-$ $0.54656 \times \mathrm{CS}^{2}-1.39583 \mathrm{E}+005 \mathrm{FR}^{2}-558.000 \times \mathrm{DOC}^{2}$

Table 3. Machining input cutting conditions and four response parameters

\begin{tabular}{|c|c|c|c|c|c|c|c|}
\hline \multirow{2}{*}{ Run order } & \multicolumn{3}{|c|}{ Input machining parameters } & \multicolumn{4}{c|}{ Response variable } \\
\cline { 2 - 7 } & $\begin{array}{c}\mathbf{C S} \\
(\mathbf{m} / \mathbf{m i n})\end{array}$ & $\begin{array}{c}\mathbf{F R} \\
\mathbf{m} \mathbf{m} / \mathbf{r e v}\end{array}$ & $\begin{array}{c}\mathbf{D O C} \\
(\mathbf{m m})\end{array}$ & $\mathbf{F}_{\mathbf{z}}(\mathbf{N})$ & $\mathbf{T}{ }^{\circ} \mathbf{C}$ & $\mathbf{R}_{\mathbf{a}}(\boldsymbol{\mu m})$ & $\mathbf{V}_{\mathbf{b}}(\mathbf{m m})$ \\
\hline 1 & 60 & 0.131 & 0.75 & 145 & 95 & 2.1 & 0.071 \\
\hline 2 & 80 & 0.131 & 1 & 692 & 125 & 1.4 & 0.087 \\
\hline 3 & 60 & 0.191 & 0.75 & 539 & 102 & 2.3 & 0.081 \\
\hline 4 & 80 & 0.191 & 1 & 828 & 130 & 1.6 & 0.092 \\
\hline 5 & 80 & 0.161 & 0.75 & 813 & 125 & 2.07 & 0.080 \\
\hline 6 & 100 & 0.161 & 1 & 823 & 137 & 2.17 & 0.107 \\
\hline 7 & 100 & 0.131 & 0.75 & 453 & 130 & 1.4 & 0.102 \\
\hline 8 & 80 & 0.191 & 0.5 & 815 & 134 & 1.93 & 0.103 \\
\hline 9 & 100 & 0.191 & 0.75 & 726 & 145 & 2.2 & 0.113 \\
\hline 10 & 80 & 0.131 & 0.5 & 263 & 109 & 1.33 & 0.078 \\
\hline 11 & 80 & 0.161 & 0.75 & 810 & 123 & 2.15 & 0.08 \\
\hline 12 & 80 & 0.161 & 0.75 & 807 & 123 & 2.05 & 0.083 \\
\hline 13 & 60 & 0.161 & 0.5 & 333 & 97 & 2.4 & 0.078 \\
\hline 14 & 100 & 0.161 & 0.5 & 548 & 134 & 1.93 & 0.103 \\
\hline 15 & 60 & 0.161 & 1 & 522 & 100 & 2.21 & 0.079 \\
\hline
\end{tabular}


International Journal of Mathematical, Engineering and Management Sciences

Vol. 4, No. 4, 905-921, 2019

https://dx.doi.org/10.33889/IJMEMS.2019.4.4-072

Table 4. ANOVA for main cutting force

\begin{tabular}{|l|c|c|c|c|c|l|}
\hline Source & SS & DF & MS & F-Value & P-Value & Remarks \\
\hline Model & $7.295 \mathrm{E}+005$ & 9 & 81055.07 & 2147.15 & $<0.0001$ & Significant \\
\hline CS & $1.278 \mathrm{E}+005$ & 1 & $1.278 \mathrm{E}+005$ & 3384.51 & $<0.0001$ & \\
\hline FR & $2.295 \mathrm{E}+005$ & 1 & $2.295 \mathrm{E}+005$ & 6079.55 & $<0.0001$ & \\
\hline DOC & $1.026 \mathrm{E}+005$ & 1 & $1.026 \mathrm{E}+005$ & 2718.00 & $<0.0001$ & \\
\hline CS $\times$ FR & 3660.25 & 1 & 3660.25 & 96.96 & 0.0002 & \\
\hline CS $\times$ DOC & 1849.00 & 1 & 1849.00 & 48.98 & 0.0009 & \\
\hline FR $\times$ DOC & 43264.00 & 1 & 43264.00 & 1146.07 & $<0.0001$ & \\
\hline $\mathrm{CS}^{2}$ & $1.765 \mathrm{E}+005$ & 1 & $1.765 \mathrm{E}+005$ & 4674.99 & $<0.0001$ & \\
\hline $\mathrm{FR}^{2}$ & 58270.67 & 1 & 58270.67 & 1543.59 & $<0.0001$ & \\
\hline DOC & 4490.83 & 1 & 4490.83 & 118.96 & 0.0001 & \\
\hline Residual & 188.75 & 5 & 37.75 & & & \\
\hline Lack of fit & 170.75 & 3 & 56.92 & 6.32 & 0.1396 & not significant \\
\hline Pure error & 1700.667 & 2 & 850.3333 & & & \\
\hline Cor total & 786434.9 & 14 & & & & \\
\hline
\end{tabular}

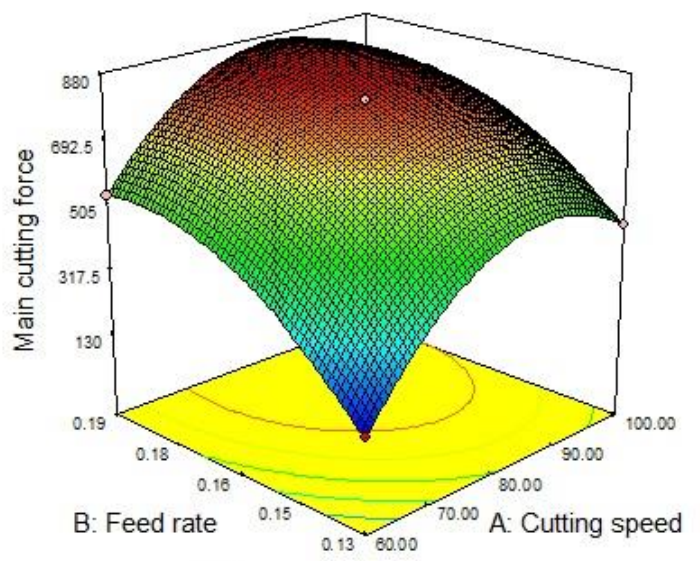

(a)

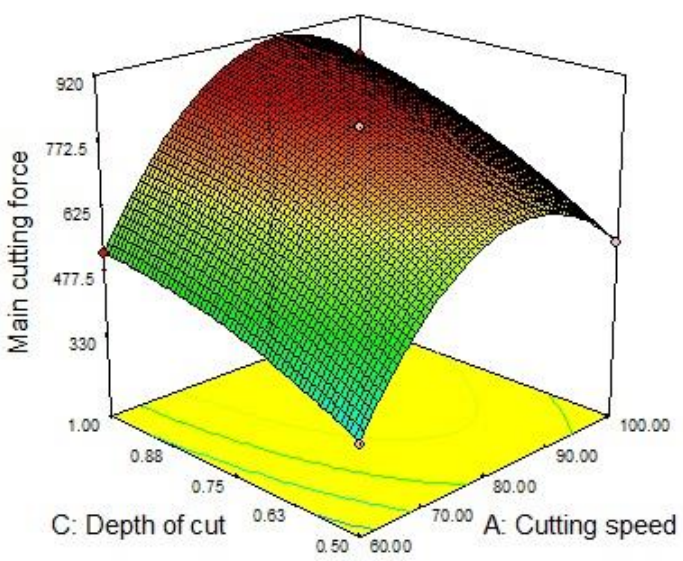

(b)

(c)

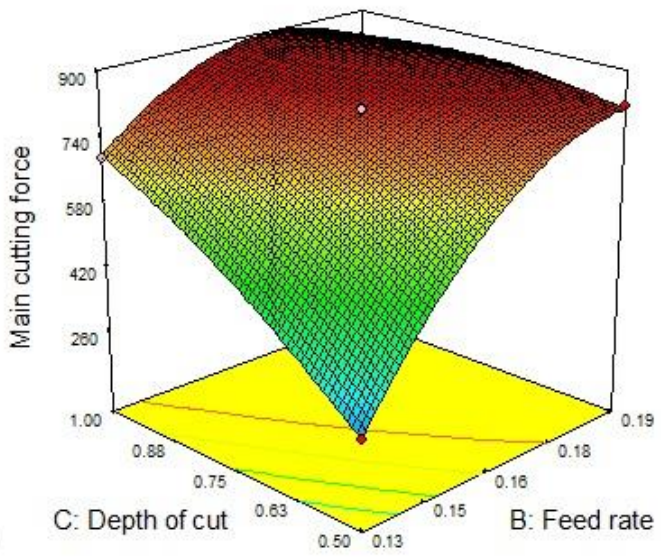

Figure 7. (a-c) esteemed response surface plot for main cutting force $\left(F_{z}\right)$ 
International Journal of Mathematical, Engineering and Management Sciences

Vol. 4, No. 4, 905-921, 2019

https://dx.doi.org/10.33889/IJMEMS.2019.4.4-072

Figure 8 (a-c) show that an increase in cutting temperature with cutting conditions CS, FR and DOC due to the generation of heat in the deformation zone. Minimum cutting temperature observed at a lower level of CS, FR and DOC. Results of ANOVA for cutting temperature are presented in Table 5. Value of the $\mathrm{P}$ for the developed regression model is less than 0.05 represent that the terms in a model have a significant effect on response. The $\mathrm{R}^{2}$ value of the regression model is 0.9952 and the value of adjusted $R^{2}$ is 0.9865 . The predicted $R^{2}$ value 0.9333 is as close as to the $\mathrm{R}^{2}$ - adjusted value. The adequate precision value 33.71 in this case is more than 4. Hence, the developed regression model for cutting temperature is desirable. The regression model for cutting temperature is as follows.

Cutting temperature $(\mathrm{T})=-111.21565+3.04667 \times \mathrm{CS}+122.03704 \times \mathrm{FR}+118.3334 \times$
$\mathrm{DOC}+3.3333 \times \mathrm{CS} \times \mathrm{FR}+0.0000 \times \mathrm{CS} \times \mathrm{DOC}-666.66667 \times \mathrm{FR} \times \mathrm{DOC}-0.01645 \times$
$\mathrm{CS}^{2}+1018.51852 \times \mathrm{FR}^{2}-1.33333 \times \mathrm{DOC}^{2}$

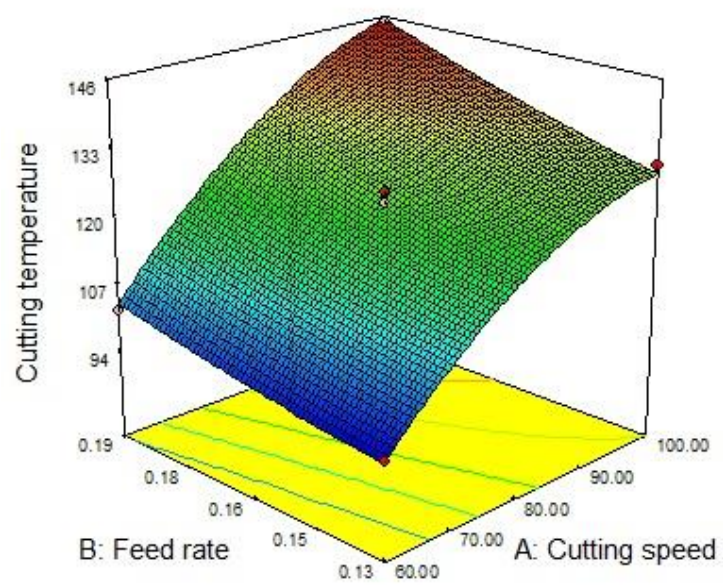

(a)

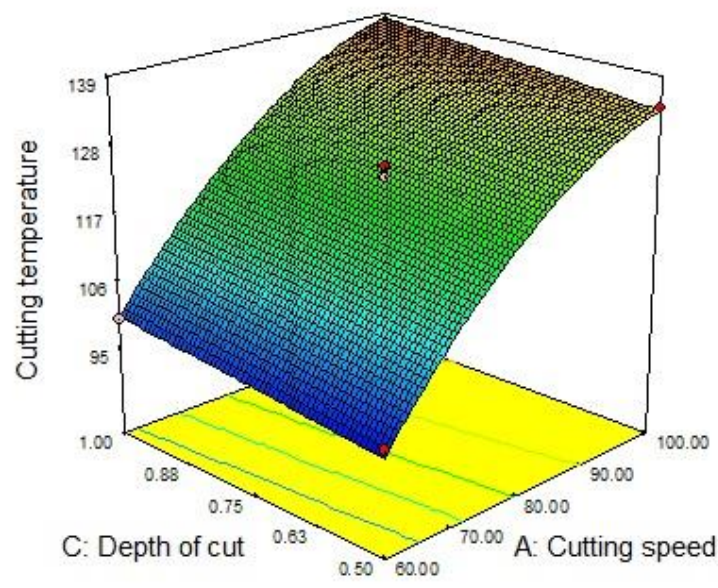

(b)

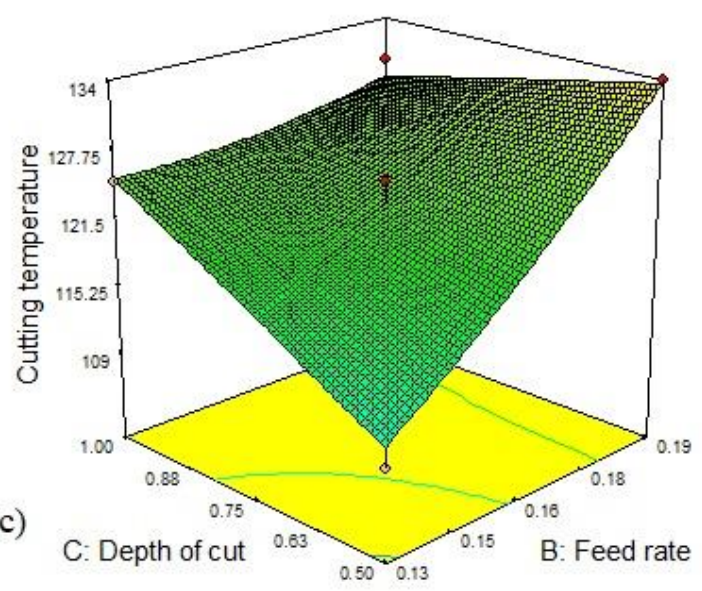

Figure 8. (a-c) esteemed response surface plot for cutting temperature 
International Journal of Mathematical, Engineering and Management Sciences

Vol. 4, No. 4, 905-921, 2019

https://dx.doi.org/10.33889/IJMEMS.2019.4.4-072

Table 5. ANOVA table for cutting temperature

\begin{tabular}{|c|c|c|c|c|c|c|}
\hline Source & SS & DF & MS & F-Value & P-Value & Remarks \\
\hline Model & 3550.43 & 9 & 394.49 & 114.90 & $<0.0001$ & Significant \\
\hline CS & 2888.00 & 1 & 2888.00 & 841.17 & $<0.0001$ & \\
\hline FR & 338.00 & 1 & 338.00 & 98.45 & 0.0002 & \\
\hline DOC & 40.50 & 1 & 40.50 & 11.80 & 0.0185 & \\
\hline $\mathrm{CS} \times \mathrm{FR}$ & 16.00 & 1 & 16.00 & 4.66 & 0.0833 & \\
\hline $\mathrm{CS} \times \mathrm{DOC}$ & 0.000 & 1 & 0.000 & 0.000 & 1.000 & \\
\hline $\mathrm{FR} \times \mathrm{DOC}$ & 100.00 & 1 & 100.00 & 29.13 & 0.0029 & \\
\hline $\mathrm{CS}^{2}$ & 160.03 & 1 & 160.03 & 16.61 & 0.0010 & \\
\hline $\mathrm{FR}^{2}$ & 3.10 & 1 & 3.10 & 0.90 & 0.3855 & \\
\hline $\mathrm{DOC}^{2}$ & 0.026 & 1 & 0.026 & $7.468 \mathrm{E}-003$ & 0.9345 & \\
\hline Residual & 17.17 & 5 & 3.43 & & & \\
\hline Lack of fit & 14.50 & 3 & 4.83 & 3.63 & 0.2237 & not significant \\
\hline Pure error & 2.67 & 2 & 1.33 & & & \\
\hline Cor total & 3567.60 & 14 & & & & \\
\hline
\end{tabular}

Influencing parameters which include $\mathrm{CS}, \mathrm{FR}$ and DOC on surface roughness $\left(\mathrm{R}_{\mathrm{a}}\right)$ in turning with aid of $2 \mathrm{wt} \%$ of $\left(\mathrm{CNT}: \mathrm{MoS}_{2}(1: 2)\right) \mathrm{HNCF}$ is illustrated with Figure $9(\mathrm{a}-\mathrm{c})$. Surface roughness $\left(\mathrm{R}_{\mathrm{a}}\right)$ is observed to decrease and then slightly increase with CS due to the vanishing of BUE on tool tip. Surface roughness $\left(R_{a}\right)$ is increased with FR and DOC due to axial movement of tool and rigidity effect of machine. The lowest surface roughness $\left(\mathrm{R}_{\mathrm{a}}\right)$ is achieved at low level of FR $(0.131 \mathrm{~mm} / \mathrm{rev})$ and DOC $(0.5 \mathrm{~mm})$ at the middle level of CS. With an increase in CS causes easier plastics deformation and chip flow during machining, which reduces the formation of BUE on cutting tool thus enhances the surface quality of workpiece (Sarikaya and Gullu, 2015). The results of the ANOVA are depicted in Table 6. P-value of the model is 0.0009 which is less than 0.05 indicate that the model is significant. The model terms CS and FR are significant where as DOC is not significant on $R_{a}$ value. The non significant terms are not counted in the building of models. The regression model $R_{a}$ with the values of $R^{2}$ and $R^{2}$ adjusted are equal to 0.9806 and 0.9455 . $R^{2}$ predicted value is 0.7340 and adequate precision value is 18.188 . The $R^{2}$ predicted value is good agreement with the value of adjusted $R^{2}$. From the $R^{2}$ value and adequate precision value it is understood that the developed model is desirable for the prediction of surface roughness $\left(R_{a}\right)$ value. The regression model for surface roughness $\left(R_{a}\right)$ is as follows.

Table 6. ANOVA table for surface roughness $\left(\mathrm{R}_{\mathrm{a}}\right)$

\begin{tabular}{|c|c|c|c|c|c|c|}
\hline Source & SS & DF & MS & F-value & P-value & Remarks \\
\hline Model & 1.67 & 9 & 0.19 & 28.01 & 0.0009 & Significant \\
\hline CS & 0.21 & 1 & 0.21 & 32.38 & 0.0023 & \\
\hline FR & 0.40 & 1 & 0.40 & 61.13 & 0.0005 & \\
\hline DOC & $5.513 \mathrm{E}-003$ & 1 & $5.513 \mathrm{E}-003$ & 0.83 & 0.4035 & \\
\hline CS $\times$ FR & 0.090 & 1 & 0.090 & 13.58 & 0.0142 & \\
\hline CS $\times$ DOC & 0.046 & 1 & 0.046 & 6.98 & 0.0459 & \\
\hline FR $\times$ DOC & 0.040 & 1 & 0.040 & 6.04 & 0.0574 & \\
\hline CS $^{2}$ & 0.25 & 1 & 0.25 & 38.04 & 0.0016 & \\
\hline FR $^{2}$ & 0.46 & 1 & 0.46 & 68.76 & 0.0004 & \\
\hline DOC $^{2}$ & 0.11 & 1 & 0.11 & 16.83 & 0.0093 & \\
\hline Residual & 0.033 & 5 & $6.625 \mathrm{E}-003$ & & & \\
\hline Lack of fit & 0.028 & 3 & $9.175 \mathrm{E}-003$ & 3.28 & 0.2425 & not significant \\
\hline Pure error & $5.600 \mathrm{E}-003$ & 2 & $2.800 \mathrm{E}-003$ & & & \\
\hline Cor total & 1.70 & 14 & & & & \\
\hline
\end{tabular}


International Journal of Mathematical, Engineering and Management Sciences

Vol. 4, No. 4, 905-921, 2019

https://dx.doi.org/10.33889/IJMEMS.2019.4.4-072

Surface roughness $\left(\mathrm{R}_{\mathrm{a}}\right)=-2.98389-0.16906 \times \mathrm{CS}+123.16944 \times \mathrm{FR}+4.49167 \times$

$\mathrm{DOC}+0.25000 \times \mathrm{CS} \times \mathrm{FR}+0.021500 \times \mathrm{CS} \times \mathrm{DOC}-13.33333 \times \mathrm{FR} \times \mathrm{DOC}+6.653 \mathrm{E}-$

$004 \times \mathrm{CS}^{2}-390.1018 .278 \times \mathrm{FR}^{2}-2.78000 \times \mathrm{DOC}^{2}$
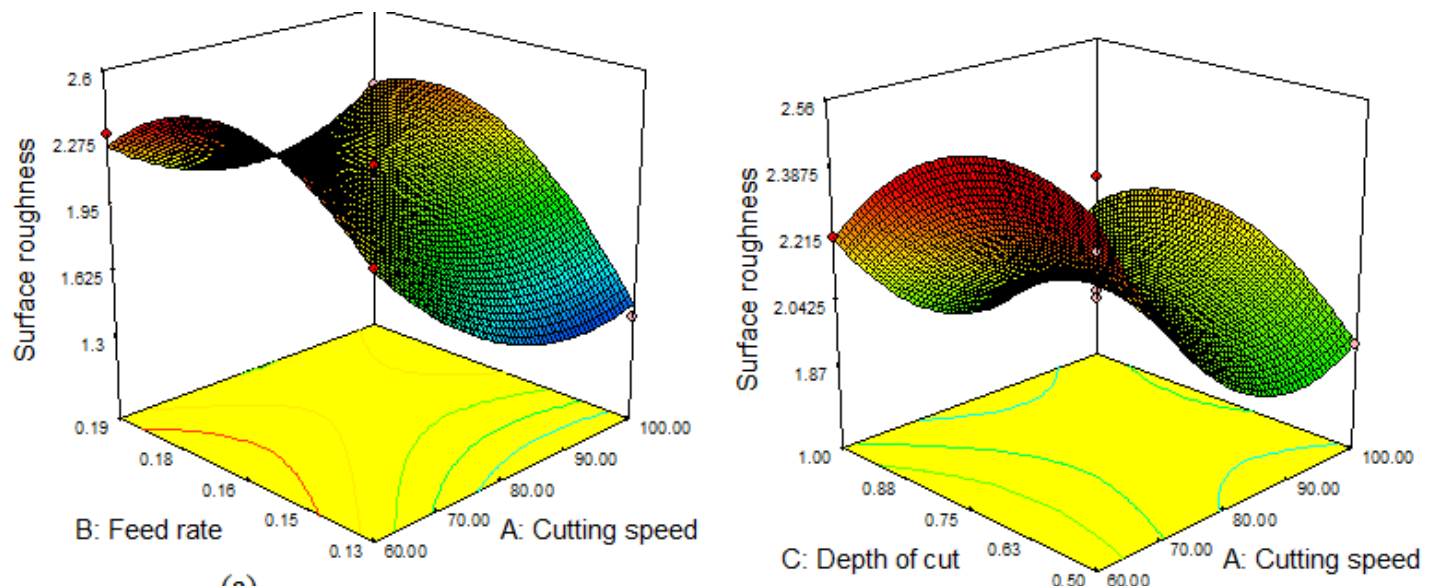

(a)

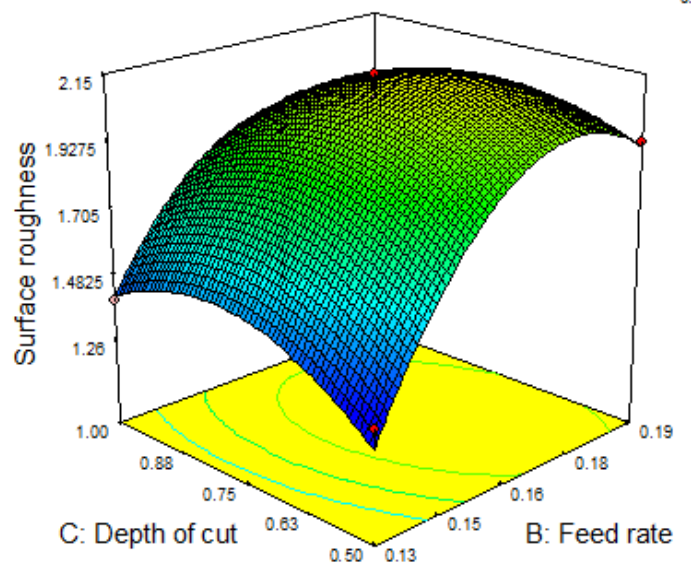

(b)

(c)

Figure 8. (a-c) esteemed response surface plot for surface roughness $\left(R_{a}\right)$

Figure 10 (a-c) show that the increase in tool flank wears with cutting conditions due to the formation of BUE on tool face, which causes to tool failure. Minimum tool flank wear is observed with the combination of the low level of CS $(60 \mathrm{~m} / \mathrm{min})$, FR $(0.131 \mathrm{~mm} / \mathrm{rev})$ at the middle level of DOC $(0.75 \mathrm{~mm})$. Results of ANOVA for tool flank wear are depicted in Table 7. P-value of the model for tool flank wear is 0.0005 , which denotes that model and its terms are significant on the response parameter. Cutting parameters CS and FR are significant on tool flank wear and DOC is not significant. The regression model values $R^{2}$ and $R^{2}$ adjusted are equal to 0.9855 and 0.9595 . The value of predicted $R^{2}$ is 80.29 , which is very near to the value of adjusted $\mathrm{R}^{2}$. Adequate precision value is 9.396 , which is greater than 4 . Hence, the developed regression model is better fitted for predicting tool flank wear. The regression model for tool flank wear is as follows. 
International Journal of Mathematical, Engineering and Management Sciences

Vol. 4, No. 4, 905-921, 2019

https://dx.doi.org/10.33889/IJMEMS.2019.4.4-072

Tool flank wear $\left(\mathrm{V}_{\mathrm{b}}\right)=+0.19163-1.95458 \mathrm{E}-003 \times \mathrm{CS}-0.93083 \times \mathrm{FR}-0.011167 \times$

$\mathrm{DOC}+4.16667 \mathrm{E}-004 \times \mathrm{CS} \times \mathrm{FR}+1.50000 \mathrm{E}-004 \times \mathrm{CS} \times \mathrm{DOC}-0.66667 \times \mathrm{FR} \times$

$\mathrm{DOC}+1.56250 \mathrm{E}-005 \times \mathrm{CS}^{2}+5.0000 \times \mathrm{FR}^{2}+0.072000 \times \mathrm{DOC}^{2}$

Table 7. ANOVA Table for tool flank wear $\left(\mathrm{V}_{\mathrm{b}}\right)$

\begin{tabular}{|c|l|l|l|l|l|l|}
\hline Source & SS & DF & MS & F-value & P-Value & Remarks \\
\hline Model & $2.367 \mathrm{E}-003$ & 9 & $2.630 \mathrm{E}-004$ & 37.84 & 0.0005 & Significant \\
\hline CS & $1.682 \mathrm{E}-003$ & 1 & $1.682 \mathrm{E}-003$ & 242.01 & $<0.0001$ & \\
\hline FR & $3.251 \mathrm{E}-004$ & 1 & $3.251 \mathrm{E}-004$ & 46.78 & 0.0010 & \\
\hline DOC & $1.125 \mathrm{E}-006$ & 1 & $1.125 \mathrm{E}-006$ & 0.16 & 0.7041 & \\
\hline CS $\times$ FR & $2.500 \mathrm{E}-007$ & 1 & $2.500 \mathrm{E}-007$ & 0.036 & 0.8570 & \\
\hline CS $\times$ DOC & $2.250 \mathrm{E}-006$ & 1 & $2.250 \mathrm{E}-006$ & 0.32 & 0.5940 & \\
\hline FR $\times$ DOC & $1.000 \mathrm{E}-004$ & 1 & $1.000 \mathrm{E}-004$ & 14.39 & 0.0127 & \\
\hline CS $^{2}$ & $1.442 \mathrm{E}-004$ & 1 & $1.442 \mathrm{E}-004$ & 20.75 & 0.0061 & \\
\hline FR $^{2}$ & $7.477 \mathrm{E}-005$ & 1 & $7.477 \mathrm{E}-005$ & 10.76 & 0.0220 & \\
\hline DOC & $7.477 \mathrm{E}-005$ & 1 & $7.477 \mathrm{E}-005$ & 10.76 & 0.0220 & \\
\hline Residual & $3.475 \mathrm{E}-005$ & 5 & $6.950 \mathrm{E}-006$ & & & \\
\hline Lack of fit & $2.875 \mathrm{E}-005$ & 3 & $9.583 \mathrm{E}-006$ & 3.19 & 0.2475 & not significant \\
\hline Pure error & $6.000 \mathrm{E}-006$ & 2 & $3.000 \mathrm{E}-006$ & & & \\
\hline Cor total & $2.402 \mathrm{E}-003$ & 14 & & & & \\
\hline
\end{tabular}
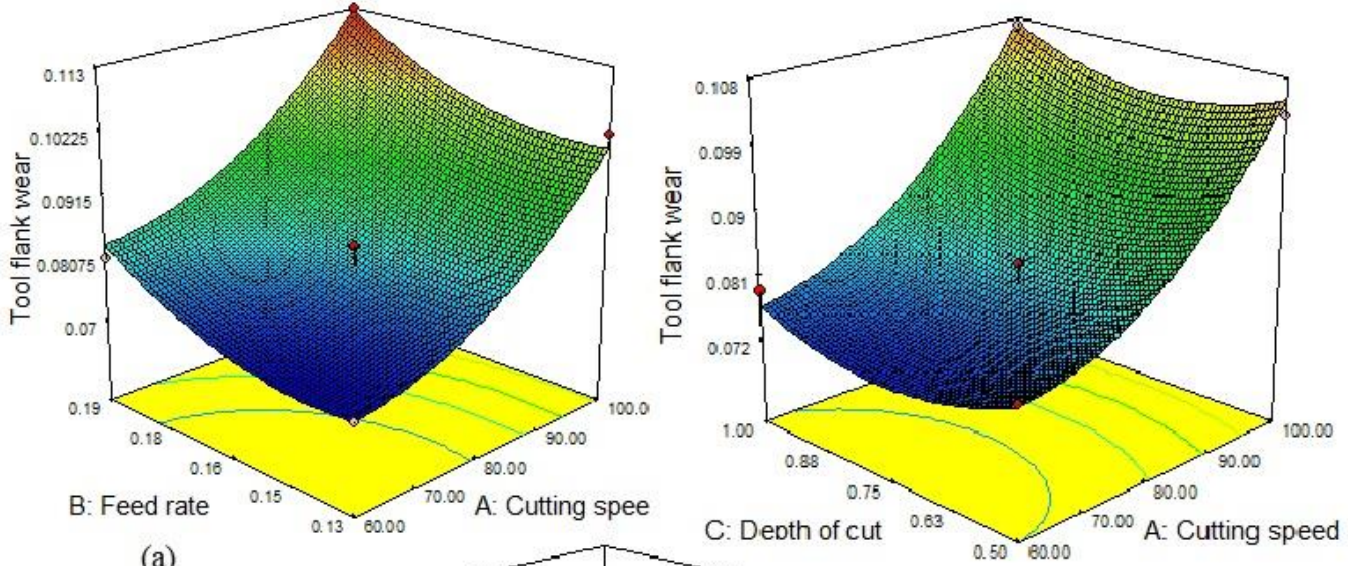

(a)

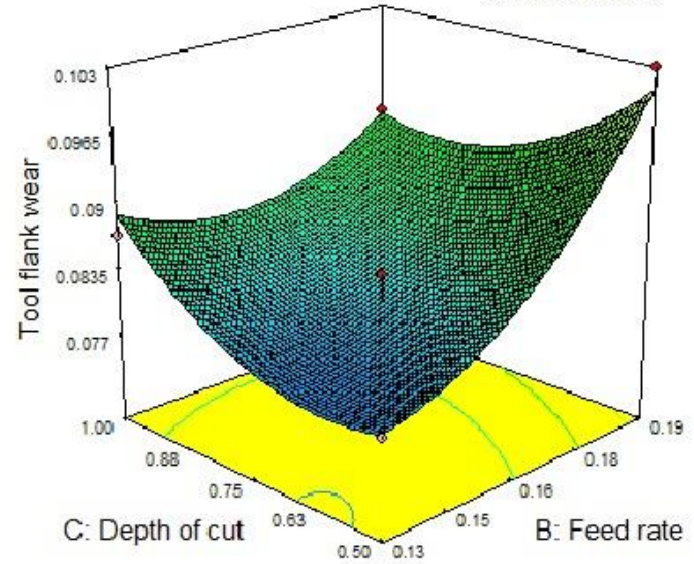

(b)

Figure 9. (a-c). Esteemed response surface plot for tool flank wear 
International Journal of Mathematical, Engineering and Management Sciences

Vol. 4, No. 4, 905-921, 2019

https://dx.doi.org/10.33889/IJMEMS.2019.4.4-072

\subsection{Optimization Using Desirability Function}

In optimization, desired goals are chosen for each cutting parameter and response parameter. Low and high-level values are set to each cutting parameter of CS, FR and DOC and goal is set in that range. The possible goals for main cutting force, tool flank wear surface roughness $\left(R_{a}\right)$ and cutting temperature are considered to be minimization. The goals of the multiple response parameters are combined into an overall desirability objective function, which is in the range of 0 to 1. Design expert software has developed model for four response parameters and optimization is carried out. The single combination of optimal setting parameters of CS, FR and DOC for the four response parameters are found to be of $70.25 \mathrm{~m} / \mathrm{min}, 0.13 \mathrm{~mm} / \mathrm{rev}$ and $0.5 \mathrm{~mm}$ at desirability value of 0.907 as shown in Figure 10 and (Table 8). Machining responses are predicted from the developed model using these optimum values and confirmation experiment is conducted by taking optimum values as cutting parameters. The predicted values and experimental values of machining responses using optimal setting parameters are also shown in Table 8. The maximum error between the values of experimental and predicted responses is found to be $8 \%$. Hence, the developed model from RSM is fit to the present problem and the optimum machining parameters obtained from the model gives the best response values for the selected HNCF.

Table 8 . The optimized and validation responses

\begin{tabular}{|c|c|c|c|c|c|c|c|c|c|c|}
\hline \multirow{2}{*}{\multicolumn{3}{|c|}{ Optimum cutting parameters }} & \multicolumn{8}{|c|}{ Machining performance } \\
\hline & & & \multicolumn{4}{|c|}{ Predicted value } & \multicolumn{4}{|c|}{ Experimental value } \\
\hline $\begin{array}{c}\mathrm{CS} \\
(\mathrm{m} / \mathrm{min})\end{array}$ & $\begin{array}{c}\text { FR } \\
(\mathrm{mm} / \mathrm{rev})\end{array}$ & $\begin{array}{l}\text { DOC } \\
(\mathrm{mm})\end{array}$ & $\begin{array}{l}\mathrm{F}_{\mathrm{z}} \\
(\mathrm{N})\end{array}$ & $\begin{array}{c}\mathrm{T} \\
\left({ }^{\circ} \mathrm{C}\right)\end{array}$ & $\begin{array}{c}\mathrm{R}_{\mathrm{a}} \\
(\mu \mathrm{m})\end{array}$ & $\begin{array}{c}\mathrm{V}_{\mathrm{b}} \\
(\mathrm{mm})\end{array}$ & $\begin{array}{l}\mathrm{F}_{\mathrm{z}} \\
(\mathrm{N})\end{array}$ & $\begin{array}{c}\mathrm{T} \\
\left({ }^{\circ} \mathrm{C}\right)\end{array}$ & $\begin{array}{c}\mathrm{R}_{\mathrm{a}} \\
(\mu \mathrm{m})\end{array}$ & $\begin{array}{c}\mathrm{V}_{\mathrm{b}} \\
(\mathrm{mm})\end{array}$ \\
\hline 70.25 & 0.131 & 0.5 & 145 & 100.89 & 1.53 & 0.073 & 158 & 105 & 1.6 & 0.081 \\
\hline
\end{tabular}
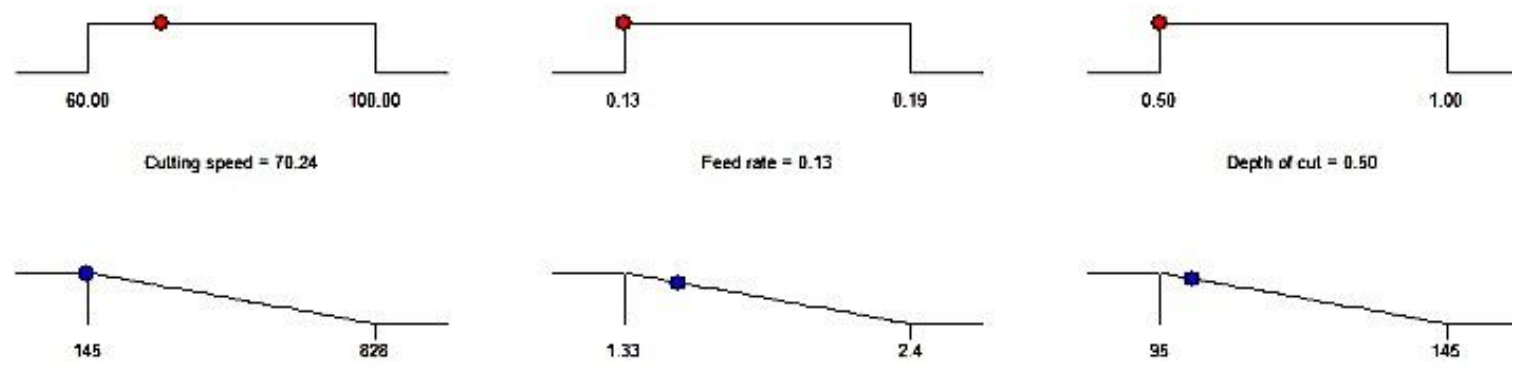

Surface roughness $=1.53398$

Depth of cut $=0.50$

Main cutting force $=144.954$

Desirability $=0.908$

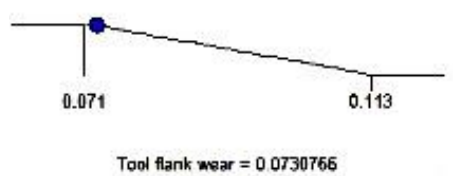

Figure 10. Ramp function graph of desirability 
International Journal of Mathematical, Engineering and Management Sciences

Vol. 4, No. 4, 905-921, 2019

https://dx.doi.org/10.33889/IJMEMS.2019.4.4-072

\section{Conclusion}

Experimental investigations are carried out under varying cutting fluid environments like dry condition, CCF, pure CNT, pure $\mathrm{MoS}_{2}$ nanofluids and CNT-MoS 2 (1:2) HNCF at constant cutting conditions in turning of AISI1040 steel. Turning experiments also carried out in varying cutting conditions using RSM technique with the use of $2 \mathrm{wt} \% \mathrm{CNT} / \mathrm{MoS}_{2} \mathrm{HNCF}$ under MQL mode and the following conclusions are drawn.

- Machining performance has been improved with $2 \mathrm{wt} \%$ of $\mathrm{CNT} / \mathrm{MoS}_{2}$ (1:2) HNCF compared to dry condition, CCF, pure CNT and pure $\mathrm{MoS}_{2}$ nanofluids.

- Significant factors on the main cutting force and cutting temperature are CS, FR and DOC. However, DOC is immaterial to surface roughness $\left(\mathrm{R}_{\mathrm{a}}\right)$ and tool flank wear compared to CS and FR.

- The value of predicted $\mathrm{R}^{2}$ and adjusted $\mathrm{R}^{2}$ are almost same for all the output responses. All the models are significant.

- Desirability test confirms that optimal setting parameters CS, FR and DOC for four response parameters are found to $70.25 \mathrm{~m} / \mathrm{min}, 0.13 \mathrm{~mm} / \mathrm{rev}$ and $0.5 \mathrm{~mm}$ at desirability value of 0.907 .

\section{Conflict of Interest}

The authors confirm that there is no conflict of interest to publish the paper in the journal.

\section{Acknowledgment}

This research article is not possible without the support of the laboratory of the Department of Mechanical Engineering. I would like to thank the National Institute of technology Warangal, Telangana, India-506004, which supported us to carry out the research work.

\section{References}

Amrita, M., Srikant, R.R., Sitaramaraju, A.V., Prasad, M.M.S., \& Krishna, P.V. (2014). Preparation and characterization of properties of nanographite-based cutting fluid for machining operations. Proceedings of the Institution of Mechanical Engineers, Part J: Journal of Engineering Tribology, 228(3), 243-252.

El-Taweel, T.A., \& Gouda, S.A. (2011). Performance analysis of wire electrochemical turning processRSM approach. The International Journal of Advanced Manufacturing Technology, 53(1-4), 181-190.

Gopalakannan, S., \& Senthilvelan, T. (2014). Optimization of machining parameters for EDM operations based on central composite design and desirability approach. Journal of Mechanical Science and Technology, 28(3), 1045-1053.

Kalita, P., Malshe, A.P., Kumar, S.A., Yoganath, V.G., \& Gurumurthy, T. (2012). Study of specific energy and friction coefficient in minimum quantity lubrication grinding using oil-based nanolubricants. Journal of Manufacturing Processes, 14(2), 160-166.

Krishna, P.V., \& Rao, D.N. (2008). Performance evaluation of solid lubricants in terms of machining parameters in turning. International Journal of Machine Tools and Manufacture, 48(10), 1131-1137.

Lawal, S.A. (2013). A review of application of vegetable oil-based cutting fluids in machining non- ferrous metals. Indian Journal of Science and Technology, 6(1).

Lawal, S.A., Choudhury, I.A., \& Nukman, Y. (2014). Evaluation of vegetable and mineral oil-in-water emulsion cutting fluids in turning AISI 4340 steel with coated carbide tools. Journal of Cleaner Production, 66, 610-618. 
International Journal of Mathematical, Engineering and Management Sciences

Vol. 4, No. 4, 905-921, 2019

https://dx.doi.org/10.33889/IJMEMS.2019.4.4-072

Marques, A., Guimarães, C., da Silva, R.B., Fonseca, M.D.P.C., Sales, W.F., \& Machado, Á.R. (2016). Surface integrity analysis of inconel 718 after turning with different solid lubricants dispersed in neat oil delivered by MQL. Procedia Manufacturing, 5, 609-620.

Mechiri, S.K., Vasu, V., \& Babu, S. (2015). Thermal conductivity of cu-zn hybrid newtonian nanofluids: experimental data and modeling using neural network. Procedia Engineering, 127, 561-567.

Padmini, R., Krishna, P.V., \& Mohana Rao, G.K. (2015). Performance assessment of micro and nano solid lubricant suspensions in vegetable oils during machining. Proceedings of the Institution of Mechanical Engineers, Part B: Journal of Engineering Manufacture, 229(12), 2196-2204.

Padmini, R., Krishna, P.V., \& Rao, G.K.M. (2016). Effectiveness of vegetable oil based nanofluids as potential cutting fluids in turning AISI 1040 steel. Tribology International, 94, 490-501.

Pasam, V.K., \& Gugulothu, S. (2018). Testing and performance evaluation of vegetable-oil-based hybrid nano cutting fluids. Journal of Testing and Evaluation, 48(5).

Paturi, U.M.R., Maddu, Y.R., Maruri, R.R., \& Narala, S.K.R. (2016). Measurement and analysis of surface roughness in WS2 solid lubricant assisted minimum quantity lubrication (MQL) turning of Inconel 718. Procedia Cirp, 40, 138-143.

Rahmati, B., Sarhan, A.A., \& Sayuti, M. (2014). Morphology of surface generated by end milling AL6061 T6 using molybdenum disulfide (MoS2) nanolubrication in end milling machining. Journal of Cleaner Production, 66, 685-691.

Rapeti, P., Pasam, V.K., Gurram, K.M.R., \& Revuru, R.S. (2018). Performance evaluation of vegetable oil based nano cutting fluids in machining using grey relational analysis-A step towards sustainable manufacturing. Journal of Cleaner Production, 172, 2862-2875.

Sarikaya, M., \& Güllü, A. (2015). Multi-response optimization of minimum quantity lubrication parameters using Taguchi-based grey relational analysis in turning of difficult-to-cut alloy Haynes 25. Journal of Cleaner Production, 91, 347-357.

Sharma, P., Sidhu, B.S., \& Sharma, J. (2015). Investigation of effects of nanofluids on turning of AISI D2 steel using minimum quantity lubrication. Journal of Cleaner Production, 108, 72-79.

Singh, R.K., Sharma, A.K., Dixit, A.R., Tiwari, A.K., Pramanik, A., \& Mandal, A. (2017). Performance evaluation of alumina-graphene hybrid nano-cutting fluid in hard turning. Journal of Cleaner Production, 162, 830-845.

Zareie, A., \& Akbari, M. (2017). Hybrid nanoparticles effects on rheological behavior of water-EG coolant under different temperatures: an experimental study. Journal of Molecular Liquids, 230, 408-414.

Zhang, Y., Li, C., Jia, D., Li, B., Wang, Y., Yang, M., \& Zhang, X. (2016). Experimental study on the effect of nanoparticle concentration on the lubricating property of nanofluids for MQL grinding of Nibased alloy. Journal of Materials Processing Technology, 232, 100-115.

Zhang, Y., Li, C., Jia, D., Zhang, D., \& Zhang, X. (2015). Experimental evaluation of MoS $_{2}$ nanoparticles in jet MQL grinding with different types of vegetable oil as base oil. Journal of Cleaner Production, 87, 930-940. 